\title{
Poverty Approach and How to Reduce it with an Agropolitan Program in Gorontalo Province, Indonesia
}

\author{
Aulia Ika Rahmawati ${ }^{1}$, Lutfi Ardianti ${ }^{1}$, Salma Hayyu Nur Husna ${ }^{1}$, Eni Paryani ${ }^{1}$, Nur Amrina Rosidhah ${ }^{1}$, Tiara \\ Putri Amalia ${ }^{1}$, and Ratih Fitria Putri ${ }^{1, *}$ \\ ${ }^{1}$ Department of Environmental Geography, Faculty of Geography, Universitas Gadjah Mada, Jl. Sekip Utara, Bulaksumur, Yogyakarta \\ 55281, Indonesia \\ ${ }^{*}$ Corresponding author: ratihfitria.putri@ugm.ac.id
}

\section{KEYWORDS \\ Agropolitan \\ Klassen typology \\ Location quotient \\ Poverty \\ Shift share}

\begin{abstract}
This study aimed to explain the conditions of poverty in Gorontalo Province, Sulawesi, Indonesia, to identify the causes of poverty in the province, and then to propose efforts to reduce this poverty. Data related to human and economic resources were used in the analysis. The condition of poverty was seen through the DPSIR approach, which consists of the driver (D), pressure (P), state (S), impact $(\mathrm{I})$, and response (R). Poverty in Gorontalo Province could be reduced by utilizing the occupation that dominates the population, which is in agriculture sector. Therefore, developing an agropolitan system is a solution. In the first stage, the location quotient (LQ), shift share (SS), and Klassen typology methods were used to determine regencies or cities that have the potential to develop an agropoli$\tan$ system. The results of the analysis showed that there were two districts that have the potential to develop agropolitan systems, namely Pohuwato Regency and Gorontalo Regency. Efforts to reduce poverty in Gorontalo Province with an agropolitan system can be continued with a second stage consisting of the preparation of products and forms of management organizations, and a third stage in the form of strengthening human resources.
\end{abstract}

(c) The Author(s) 2019. This article is distributed under a Creative Commons Attribution-ShareAlike 4.0 International license.

\section{INTRODUCTION}

Gorontalo Province is located near the equator, between $0^{\circ} 19^{\prime}-0^{\circ} 57^{\prime} \mathrm{N}$ and $121^{\circ} 23^{\prime}-125^{\circ} 14^{\prime}$ E. Administratively, it has six regions that comprise five regencies and one city (Figure 1). These administrative regions are Boalemo Regency, Pohuwato Regency, Bone Bolango Regency, Gorontalo Regency, North Gorontalo Regency, and Gorontalo City. Based on its geographical position, the borders of Gorontalo Province consistent of the Sulawesi Sea to the north, Tomini Bay to the south, Central Sulawesi Province to the west, and North Sulawesi Province to the east. Gorontalo Province has an area of $12,435 \mathrm{~km}^{2}$ or $0.63 \%$ of the total area of Indonesia, and is dominated by hills.

The main problem that cannot be fully solved in Gorontalo Province is poverty. Poverty is an inability to fulfill basic rights (Aneta 2010). Poverty became of the problems to be raised globally through the United Nations' Sustainable Development Goals (Yulianto et al. 2019), where it was listed as the first problem to be overcome. The target is to eliminate poverty for everyone, wherever they are, who live on less than USD 1.25 per day. In September 2017, there were $17.14 \%$ of poor people from the total population in Gorontalo Province (Statistics Indonesia 2019). Gorontalo Province is ranked $5^{\text {th }}$ for the highest poverty rate in Indonesia, after Maluku Province.

Various efforts have been made by the regional government to overcome the problem of poverty in Gorontalo Province. For instance, the Gorontalo Provincial Bank
Indonesia Representative Office (Kantor Perwakilan Bank Indonesia Provinsi Gorontalo) has explained that the Gorontalo Provincial Government, through the Gorontalo Provincial Social Service, has conducted various programs by establishing the Regional Poverty Reduction Coordination Team (Tim Koordinasi Percepatan Penanggulangan Kemiskinan Daerah, or TKPPKD), whose programs are included in the Gorontalo Province Medium-Term Development Plan (Rencana Pembangunan Jangka Menengah

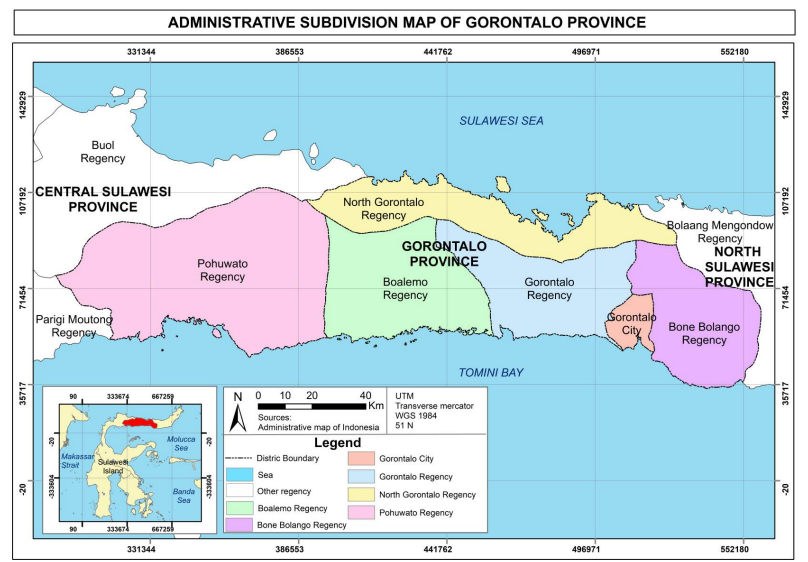

FIGURE 1. Administrative subdivision map of Gorontalo Province. Source: Statistics Indonesia (2019). 
Daerah, or RPJMD) for the years 2018-2022. These programs consist of initiatives handling the poor, social empowerment programs, health insurance and protection programs, and social rehabilitation programs. However, these poverty reduction programs are still focused on the kind of poverty that is commonly happening around the globe. It is necessary carry out other poverty reduction programs that are more specific and also appropriate with natural and human conditions in Gorontalo Province.

Agriculture is the main sector supporting growth in Gorontalo Province. The farming scale in Gorontalo Province is small, so income is also small. Organizing the small farms into an agriculture cluster area is one option to solve the problem. Agriculture cluster area is a generic concept that in practice has been given various names, such as agropolitan and agriculture production center (Helmi et al. 2019). Agropolitan is an agricultural city that is able to grow and develop due to the running of the systems and the works in agribusinesses, as well as being able to serve, encourage, and attract agricultural development activities (agribusinesses) in adjacent areas (Department of Agriculture of the Republic of Indonesia 2002). The purposes of this study were (1) explain the conditions of poverty in Gorontalo Province, (2) identify causes of poverty in Gorontalo Province, and (3) identify efforts to reduce poverty in Gorontalo Province.

\section{METHODS}

\subsection{Data types and source}

The data used in this study consisted of secondary data obtained from results published by Statistics Indonesia (2019). The data included the population of Gorontalo Province, the population of both the labor force and non-labor force, the number and percentage of Gorontalo Province's poor population, the human development index value of each indicator, the economic growth of each regency or city, Gross Domestic Regional Product (GDRP) per capita in each regency or city, and GDRP according to each sector in each regency or city in Gorontalo Province.

The poverty phenomenon in Gorontalo Province was analyzed using the DPSIR model. The DPSIR model consists of five indicators - the driver (D), pressure (P), state (S), impact (I), and response (R)-which are used to analyze the phenomenon of poverty. The poverty analysis in Gorontalo Province using the DPSIR model is shown in Figure 2.

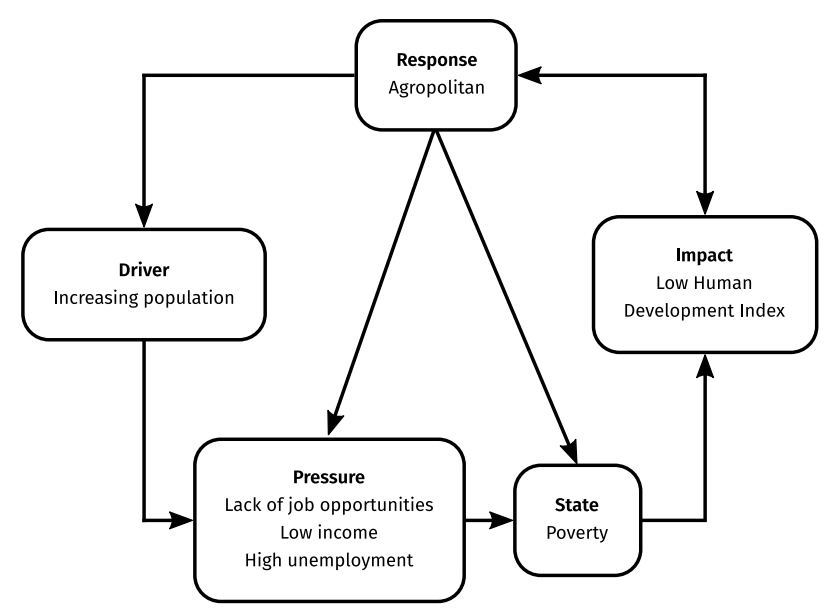

FIGURE 2. DPSIR model. Source: Statistics Indonesia (2019).

\subsection{Data analysis}

\subsubsection{Location quotient (LQ) analysis}

Location quotient (LQ) analysis was used to find out the specialization of economical activities and get a picture in the determination of leading sectors as a leading sector in an economic activity (Hendayana 2003). The LQ value was used as a basis to determine the leading sectors of each regency or city in Gorontalo Province. The leading sector was the sector with the highest potential to be developed because it can meet the needs of its own region as well as those of the surrounding area. This method was used with the assumption that the geographical conditions were uniform, activity patterns were uniform, and that every activity produced the same product. The formula for Gorontalo Province's location quotient is shown in Equation 1.

$$
\mathrm{LQ}=((\mathrm{GDRP} i k / \mathrm{GDRP} k)) /((\mathrm{GDRP} i p / \mathrm{GDRP} p))
$$

where GDRPik is the RP of the $i$ sector in a regency, GDRPk is the total GDRP in a regency, GDRPip is the GDRP of the $i$ sector in the province, and GDRP $p$ is the total GDRP in the province.

Based on the LQ calculation, the concentration of economic activities in a region will be known. An LQ value > 1 indicates that the sector is a leading sector and an economic base. An LQ value < 1 indicates that the sector is not a leading sector and not an economic base in the region.

\subsubsection{Shift share (SS) analysis}

Shift share (SS) analysis was used to identify and analyze the competitive advantage of a commodity, wherein the competitive advantage is the ability of a region to market its products outside the region, abroad, or in global markets (Robinson 2005). Shift share calculations can be done by dividing growth as a change (D) in a regional variable, national growth $(\mathrm{N})$, industrial mix $(\mathrm{M})$, and competitive advantage $(\mathrm{C})$, which is called classic shift share analysis. For the $i$ sector in the region $j$, it is formulated as in Equations 2 and 3 (Perloff et al. 1960):

$$
D_{i j}=N_{i j}+M_{i j}+C_{i j}
$$

where $\mathrm{D} i \mathrm{j}$ is the performance of the $i$ sector in the $j$ region, $\mathrm{N} i j$ is the growth of the $i$ sector in the $j$ region, Mij is the industrial mix of the $i$ sector in the $j$ region, and $C i j$ is the competitive advantage of the $i$ sector in the $j$ region.

$$
S N_{i j}=M_{i j}+C_{i j}
$$

where $\mathrm{SN} i j$ is the shift netto, Mij is the industrial mix of the $i$ sector in the $j$ region, and $\mathrm{C} i j$ is the competitive advantage of the $i$ sector in the $j$ region.

Positive and high values of $D_{i j}$ indicate that the performance of the sector is superior to the economic performance of the region that is being compared (Nugroho 2012).

\subsubsection{Klassen typology analysis}

Klassen typology analysis was used to describe the pattern and structure of regional economic growth in Gorontalo Province (Sutikno and Maryunani 2007; Dwiputra et al. 2019). The indicators used were GDRP per capita and the growth rate of GDRP. The results of klassen typology are 
contained across four categories of regional criteria, which are (Muta'ali 2015):

1. Fast growing regions, which have economic growth rates and per capita GRDP greater than the average regency or city in the province.

2. Developing regions, which have high economic growth rates, but GRDP per capita is lower than the average regency or city in the province.

3. Advanced but depressed regions, which have low economic growth rates, but GRDP per capita is higher than the average regency or city in the province.

4. Relatively lagging regions, which have economic growth rates and GRDP per capita that are lower than the average regency or city in the province.

\section{RESULTS AND DISCUSSION}

\subsection{Poverty approach}

Poverty that is related to monetary in Gorontalo Province was analyzed using the DPSIR model. The indicators in this model will form a pattern that can be used to analyze a phenomenon, including poverty. More appropriate decisions to deal with a problem can then be taken so that the solution becomes more effective and efficient. This is what underlies the use of the DPSIR method to assess poverty in Gorontalo Province. The results of the poverty analysis in Gorontalo Province using the DPSIR method are as follows.

\subsubsection{Causes of poverty ( $D$ and $P$ indicators)}

Poverty that occurs in an area can be caused by two factors, namely external or internal factors. Internal factors are in the form of attitudes or behaviors, experiences and observations, personalities, concepts, motives, and perceptions, while external factors include reference groups, family, social class, and culture (Tazkiya 2015). Limited employment is one of the driving factors of poverty in Gorontalo Province, due to the increasing population each year. This condition is in accordance with the causes of problems of poverty in general that occur in Indonesia, according to (Hudaya 2009), which includes education that is too low, laziness to work, limited natural resources, limited employment, limited capital, and the existence of family burdens.

According to Statistics Indonesia (2019), the population of Gorontalo Province numbered 1,168,190 in 2017. Population increase is affected by birth, death, and migration. In general, the rise in the population of Gorontalo Province is influenced more by the process of birth and death than migration. This shows that the lifetime migration rate in
Gorontalo Province is not high and out-migration has a higher number compared with in-migration.

Population analysis is important to the understanding of the social aspect in poverty and one of economic resources analysis (Putri et al. 2018, 2019). The population in Gorontalo Province, although it has increased every year in the period of 2013-2017, the population growth rate of Gorontalo Province has tended to decline. The Gorontalo Provincial Government has succeeded in reducing population growth rates more than some of the other provinces in Indonesia and it is lower than the national population growth rate in the five-year period shown in Figure 3. The population that continues to increase significantly in Gorontalo Province is very important to note, even though population growth continues to decline.

An increase in the population of Gorontalo Province will impact its employment situation, which is reflected in its labor force and non-labor force. The labor force is the part of the population that works or is looking for work, including open unemployment. Meanwhile, the non-labor force consists of housewives, residents who attend school, and retirees. The number of the labor force in Gorontalo Province increased every year for the years 2012-2017, as is illustrated in Figure 4. The increasing number of the labor force needs to be balanced with an increase in employment, so that the unemployment rate there can be reduced.

A population increase in general is the main trigger of poverty in Gorontalo Province because the increase in the population is not proportional to the increase in employment. The poverty in Gorontalo Province generally is structural poverty, which is a poor condition caused by the inability of the system and social structure to supply employment opportunities for the community. Limited employment in Gorontalo Province puts pressure on the population that does work. The high labor force number, which is not balanced with adequate employment opportunities, will have an impact on unemployment. In addition, the number of the labor force that does not have good competence results in the absorption of labor in a group of uneducated and untrained workers. This has an effect on the low amount of income.

Data on employment in Gorontalo Province for the years 2013-2017 showed that the largest absorber of labor was in the agricultural sector, $33.81 \%$, while the lowest was in the industrial sector, at $6.16 \%$. The data show that livelihoods are dominated by farmers and the economy in the province is strongly supported by the agricultural sector. Employment in the agricultural sector has a significant contribution to its GDRP, which was at 37\%. Even though the agricultural sector is able to absorb quite a lot of labor, the

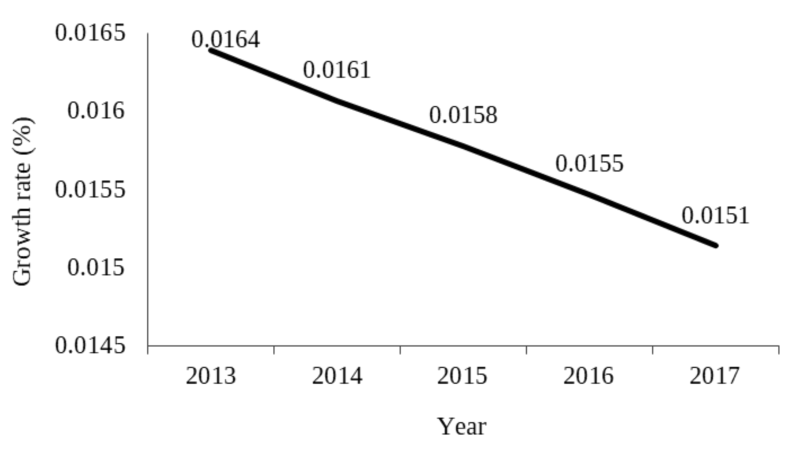

FIGURE 3. Total migration in Gorontalo Province in 2000-2015. Source: Statistics Indonesia (2019).

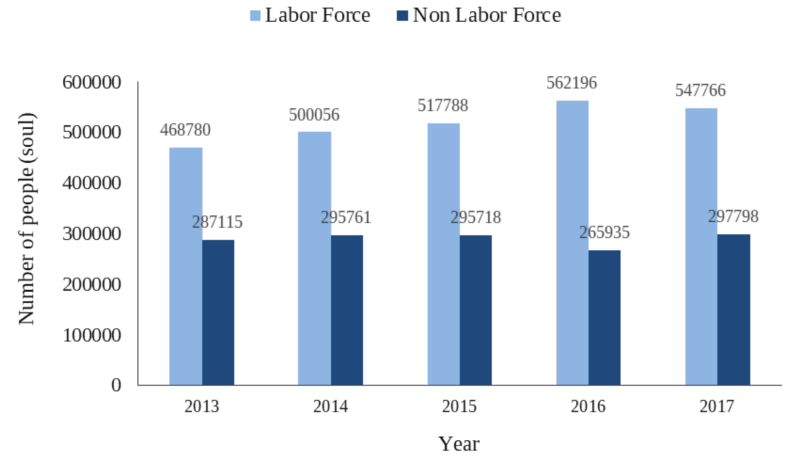

FIGURE 4. Population in Gorontalo Province in 2013-2017. Source: Statistics Indonesia (2019). 
absorbed labor force does not work fully, which can lead to seasonal unemployment in Gorontalo Province.

The exchange rate of farmers in Gorontalo province amounted to 105.46 in 2016, which is above the national farmer exchange rate of 101.65 (Figure 5). The agricultural exchange rate itself is a comparison between the price index received by farmers (It) with the price index paid by farmers (Ib). A farmer's exchange rate of more than 100 (NTP > 100) shows that the farmers experience a surplus, where the price of production rises is greater than the increase in the price of consumption, so that the farmers' income increases more than their expenditure. The farmer exchange rate in Gorontalo Province, which was high, shows that the agricultural sector there has very high potential. Therefore, development in the agricultural sector is one of the things that can be done to support the reduction of poverty rates in the province.

The high unemployment rate in Gorontalo Province is closely related to the lack of job opportunities there. This condition is also caused by Gorontalo Province having been formed only recently, specifically in 2000 , which results in a lack of preparedness from the government in preparing jobs that are in accordance with the skills of the community. The lack of community skills in Gorontalo Province also has an impact on their opportunities to work in sectors with high income. The agricultural sector consequently became the province's solution to provide work even with a lack of experience and skills. Poverty in Gorontalo Province, as shown in Table 1, is recognized as a result of low income, and is also driven by high household consumption expenditures, which accounted for $61.48 \%$ of the GDP.

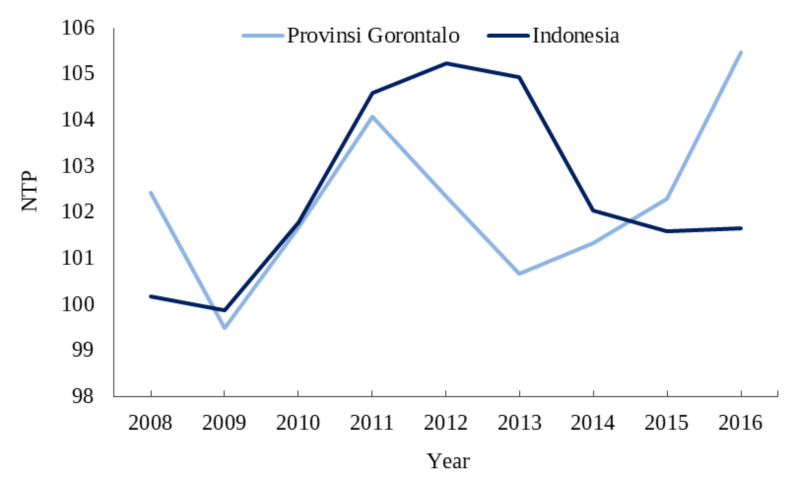

FIGURE 5. Farmer exchange rates in Gorontalo Province and Indonesia in 2008-2016. Source: Statistics Indonesia (2019).

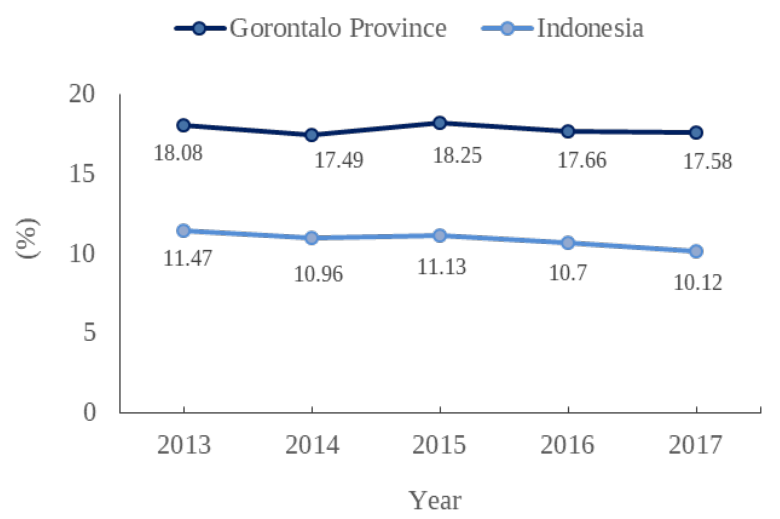

FIGURE 6. Percentage of poor people in Gorontalo Province in 2013-2017. Source: Statistics Indonesia (2019).
3.1.2 State of poverty (S indicator, poverty line, depth, and severity of poverty)

Poverty is a state that is still faced by many people in Gorontalo province. Poverty is the condition of someone or a group of people with the inability to meet their basic needs, where their per capita expenditure is still below the poverty line. Poverty is closely related to economic development, which can be seen through economic growth rate.

Gorontalo Province was found to have higher economic growth than the national economic growth rate. This indicates that Gorontalo province had a good and fast economic development, and as its result, the people became more prosperous. Despite this, the reality in the field showed that the high economic growth has not been enjoyed by all of the people in society evenly. As a result, this condition causes the economy in general to fail to reach the level of expected welfare. This is indicated by the percentage of poor people in Gorontalo Province, which is still high. Figure 6 shows that the percentage of poor people in Gorontalo province is higher than the national level for the period of 2013-2017.

Although the percentage of poverty in Gorontalo Province shows a declining trend from year to year (Figure 6 ), when compared with other provinces in Indonesia, the poverty rate in Gorontalo Province is still relatively high. Gorontalo province is fifth, after Papua, West Papua, East Nusa Tenggara, and Maluku, in terms of the highest percentage of poor people. The percentage of poor people in Gorontalo also ranks highest on the island of Sulawesi.

In general, poverty in Gorontalo Province occurs not because of the inability of the poor to work, but also because of the inability of the social systems and structures to provide employment opportunities to the residents, a form of poverty known as structural poverty. The pattern of poverty that occurs in Gorontalo Province is one that is persistent, as it occurs from generation to generation.

The poverty assessment in Gorontalo Province is based on the poverty line, depth, and severity of poverty. The poverty line is based on per capita expenditure in the area, where inflation and market prices are very influential. The higher the poverty line, the higher the expenditure will be, which indicates that income will also be higher, so that the poverty rate is lowered. The highest poverty line in Gorontalo Province was in Gorontalo City, while the lowest was in Pohuwato and North Gorontalo.

The depth index of poverty and poverty severity index are indicators that are used to measure poverty levels in an area. The depth index of poverty shows the distance between the poverty line and the poorest in the population. Gorontalo City had the lowest poverty depth index

TABLE 1. Annual GRDP percentage according to expenditures in Gorontalo Province in 2017.

\begin{tabular}{lc}
\hline Components of distribution & $\begin{array}{c}\text { Percentage distribution } \\
\text { of GDRP yearly } \\
\text { expenditures (\%) }\end{array}$ \\
\hline Household consumption expenditures & 61.48 \\
LNPRT expenditures & 0.71 \\
Government consumption expenditures & 22.6 \\
Formation of gross fixed invest & 29.85 \\
Change in inventory & 2.28 \\
Export of goods and services & 22.4 \\
Import of goods and services & 39.32 \\
\hline
\end{tabular}


compared with the other districts. This shows that poor people in Gorontalo City are classified as not very poor because their expenditure is not too far from the poverty line. Meanwhile, the severity index shows distance of expenditure between poor people. The higher the severity index of poverty, the higher the gap between poor people will be. The lowest severity index in Gorontalo Province was also found in Gorontalo City. The lowest poverty depth and severity index, found in Gorontalo City as mentioned, is comparable to the percentage of poor people who are also the lowest compared with the other districts.

The characteristics of poor people in Gorontalo are dominated by people who live in rural areas and work as farmers. Based on data from Statistics Indonesia on Gorontalo province, in 2017, the number of poor people in Gorontalo who work as farmers was greater than $60 \%$. Meanwhile, when it is viewed from the highest level of education achieved, there were $33.30 \%$ of poor people in Gorontalo Province that were unable to complete elementary education. Part of the characteristics of the poor in Gorontalo Province described above are in accordance with the characteristics of the poor people proposed by (Tazkiya 2015), who mentions that the poor generally live in rural areas with basic livelihoods in the agricultural sector and other economic activities related to traditional sectors.

\subsubsection{Impact of poverty (I indicator)}

The human development index (HDI) is a comparative measurement of life expectancy, literacy, education and living standards for all countries throughout the world (Davies and Quinlivan 2006). It is used to classify whether a country is a developed country, developing country, or underdeveloped country, as well as to measure the influence of economic policy on quality of life. The HDI of Gorontalo Province in 2017 was among the lowest seven provinces in Indonesia, At 67.01, it was classified as moderate based on Statistics Indonesia's standards. The HDI was also below the national HDI of 70.81. This shows that the quality of Gorontalo Province's human resources, both physically and non-physically, is still below national standards. Gorontalo Province's HDI increased from 2010 to 2017, but was nevertheless still continued to be below the national standard during this period.

Per capita expenditure is seen as reflecting the welfare of the population, especially in economic terms. Expenditures can also be interpreted as consumption. People have a tendency to increase consumption when they increase in income. This means that higher income will lead to higher consumption as well, while contrarily, if the income decreases, the consumption will also decrease.

Population income affects the HDI positively. Income and expenditure also have a relationship that is directly proportional, so when expenditure increases, the HDI will also increase. The relationship between HDI and per capita expenditure in Gorontalo Province over the period of 20102017 is proving this. In 2010, when the per capita expenditure was at its lowest (at Rp8,207,000), the HDI was also the lowest in the eight-year period, at 62.65. Meanwhile, Gorontalo Province had its highest HDI and per capita expenditure both occur in 2017, with per capita expenditure being Rp9,532,000 and the HDI consequently being 67.01 .

TABLE 2. Location quotients of regencies/cities and business fields in Gorontalo Province in 2010, 2014, and 2017 (Statistics Indonesia 2019).

\begin{tabular}{|c|c|c|c|c|c|c|c|c|c|c|c|c|c|c|c|c|c|c|}
\hline \multirow[t]{2}{*}{ Business Field } & \multicolumn{3}{|c|}{ Boalemo } & \multicolumn{3}{|c|}{ Gorontalo } & \multicolumn{3}{|c|}{ Pohuwato } & \multicolumn{3}{|c|}{ Bone Bolango } & \multicolumn{3}{|c|}{ Gorontalo Utara } & \multicolumn{3}{|c|}{ Kota Gorontalo } \\
\hline & 2010 & 2014 & 2017 & 2010 & 2014 & 2017 & 2010 & 2014 & 2017 & 2010 & 2014 & 2017 & 2010 & 2014 & 2017 & 2010 & 2014 & 2017 \\
\hline $\begin{array}{l}\text { Agriculture, Forestry, } \\
\text { and Fisheries }\end{array}$ & 1.50 & 1.46 & 1.41 & 1.03 & 1.07 & 1.05 & 1.51 & 1.56 & 1.56 & 0.97 & 0.95 & 0.97 & 1.28 & 1.29 & 1.33 & 0.16 & 0.14 & 0.13 \\
\hline $\begin{array}{l}\text { Mining and } \\
\text { Excavation }\end{array}$ & 0.33 & 0.35 & 0.38 & 1.40 & 1.51 & 1.53 & 0.95 & 0.85 & 0.73 & 1.61 & 1.49 & 1.27 & 1.54 & 1.66 & 1.65 & 0.31 & 0.28 & 0.28 \\
\hline Processing Industry & 0.46 & 0.47 & 0.48 & 0.99 & 1.05 & 1.03 & 1.10 & 1.08 & 1.07 & 1.52 & 1.50 & 1.63 & 0.50 & 0.47 & 0.44 & 1.17 & 1.12 & 1.14 \\
\hline $\begin{array}{l}\text { Procurement of } \\
\text { Electricity, Gas }\end{array}$ & 0.31 & 0.36 & 0.39 & 1.55 & 1.52 & 1.49 & 0.80 & 0.86 & 0.92 & 0.61 & 0.58 & 0.34 & 0.55 & 0.63 & 0.66 & 1.14 & 1.08 & 1.03 \\
\hline $\begin{array}{l}\text { Water Supply, Trash, } \\
\text { Waste and Recycling } \\
\text { Management }\end{array}$ & 0.44 & 0.37 & 0.36 & 0.39 & 0.43 & 0.42 & 0.52 & 0.50 & 0.52 & 0.45 & 0.54 & 0.57 & 0.22 & 0.22 & 0.22 & 3.23 & 3.00 & 3.00 \\
\hline Construction & 0.57 & 0.58 & 0.61 & 1.39 & 1.28 & 1.30 & 0.60 & 0.54 & 0.55 & 0.81 & 0.91 & 1.05 & 0.87 & 0.88 & 0.89 & 1.14 & 1.16 & 1.21 \\
\hline $\begin{array}{l}\text { Large and Retail } \\
\text { Trade }\end{array}$ & 0.89 & 1.05 & 1.11 & 0.81 & 0.77 & 0.75 & 0.88 & 0.90 & 0.93 & 1.17 & 1.15 & 1.22 & 0.87 & 0.82 & 0.80 & 1.41 & 1.37 & 1.34 \\
\hline $\begin{array}{l}\text { Transportation and } \\
\text { Warehousing }\end{array}$ & 0.41 & 0.41 & 0.42 & 1.34 & 1.37 & 1.41 & 0.47 & 0.55 & 0.56 & 0.21 & 0.20 & 0.19 & 0.74 & 0.67 & 0.64 & 1.78 & 1.67 & 1.63 \\
\hline $\begin{array}{l}\text { Accommodation and } \\
\text { Drinking Providers }\end{array}$ & 0.51 & 0.56 & 0.57 & 0.93 & 0.88 & 0.87 & 0.56 & 0.52 & 0.51 & 0.55 & 0.50 & 0.48 & 0.81 & 0.80 & 0.77 & 2.07 & 2.22 & 2.19 \\
\hline $\begin{array}{l}\text { Information and } \\
\text { Communication }\end{array}$ & 0.50 & 0.53 & 0.52 & 1.07 & 1.06 & 1.03 & 0.50 & 0.51 & 0.50 & 0.68 & 0.71 & 0.59 & 0.60 & 0.63 & 0.62 & 1.92 & 1.88 & 1.85 \\
\hline $\begin{array}{l}\text { Financial and } \\
\text { Insurance Services }\end{array}$ & 0.44 & 0.49 & 0.56 & 1.07 & 1.04 & 1.04 & 0.52 & 0.51 & 0.52 & 0.43 & 0.53 & 0.55 & 0.15 & 0.18 & 0.17 & 2.25 & 2.16 & 2.12 \\
\hline Real estate & 0.60 & 0.69 & 0.69 & 0.52 & 0.56 & 0.55 & 0.48 & 0.47 & 0.47 & 1.54 & 1.37 & 1.32 & 0.76 & 0.74 & 0.71 & 2.17 & 2.17 & 2.23 \\
\hline Company Services & 0.59 & 0.58 & 0.58 & 0.76 & 0.73 & 0.71 & 1.09 & 0.97 & 0.96 & 1.08 & 1.32 & 1.38 & 0.48 & 0.56 & 0.58 & 1.69 & 1.67 & 1.74 \\
\hline $\begin{array}{l}\text { Government } \\
\text { Administration }\end{array}$ & 0.95 & 0.99 & 1.01 & 0.59 & 0.60 & 0.60 & 0.66 & 0.66 & 0.66 & 1.40 & 1.41 & 1.25 & 1.02 & 1.18 & 1.19 & 1.70 & 1.63 & 1.61 \\
\hline Education Services & 0.87 & 0.84 & 0.86 & 0.82 & 0.78 & 0.81 & 0.59 & 0.55 & 0.55 & 1.13 & 1.12 & 1.08 & 0.75 & 0.76 & 0.76 & 1.70 & 1.82 & 1.82 \\
\hline $\begin{array}{l}\text { Health Services and } \\
\text { Social Activities }\end{array}$ & 1.01 & 0.99 & 1.02 & 0.76 & 0.81 & 0.81 & 0.72 & 0.70 & 0.68 & 1.39 & 1.43 & 1.38 & 0.92 & 1.02 & 1.01 & 1.37 & 1.31 & 1.26 \\
\hline Other services & 0.86 & 0.83 & 0.90 & 0.83 & 0.83 & 0.82 & 0.66 & 0.71 & 0.71 & 1.19 & 1.25 & 1.14 & 1.09 & 1.13 & 1.12 & 1.47 & 1.49 & 1.51 \\
\hline
\end{tabular}




\subsubsection{Response ( $\mathrm{R}$ indicator)}

Programs for handling poverty in Gorontalo Province, as mentioned before, consist of initiatives for the handling of the poor, social empowerment programs, health insurance and protection programs, and social rehabilitation programs. These programs are still general. Therefore, efforts are needed that are in accordance with the causes of poverty in Gorontalo Province in particular.

\subsection{Linkage of DPSIR indicators}

These indicators each have a position that, if linked, can create a solution by utilizing the advantages (potential) that exist in the area. This potential is implicitly one of the considerations that can be taken to make a response. This invisible point is what is actually important. Seeing that the DPSIR model facilitates decision-making by considering problems directly from its roots, sometimes what is not seen becomes less noticed, such as this potential of the area.

The DPSIR model also conveys a simple message that the driver-pressure-state to impact had a unilateral effect, but the response is flexible so that it can be applied through the other four indicators. The root problem of poverty in Gorontalo Province, as has been discussed, is the population. The population in general has been handled by the government through family planning and education programs. This shows that there has been a response to the driver indicator specifically. What is left to do is to apply the response to the remaining three indicators. By utilizing the potential, the response that is appropriate to the state of the region will be carried out more easily and effectively.

\subsection{Agropolitan, an effort to reduce poverty in Gorontalo Province}

The problem of poverty needs to be handled in accordance with the state of poverty in Gorontalo Province, which is by improving the management of the agricultural sector, so it will able to absorb a lot of labor and have high productivity. The already-developed agricultural system must also involve other sectors so that they are mutually integrated and more labor is absorbed in a series of economic activities ranging from input to consumers (Fatkhiati et al. 2015). The solution can be realized by planning an agropolitan program in areas in the province that have an agricultural base.

Agropolitan is a type of bottom-up development concept that aims to build an agriculture-based economy in the selected region, to improve the prosperity and welfare of rural communities, and to serve, encourage and spur multi-sectoral and multidisciplinary agricultural development in the surrounding area. Agropolitan programs have three stages: location determination, preparation of spatial products and management organization forms according to needs, and strengthening human and institutional resources (Suroyo and Handayani 2014). Determination of location is performed by determining regencies or cities that have the agricultural sector as a leading sector and have advanced and rapidly developing regional economic growth that enable them to support multi-sectoral activities in agropolitan programs. The determination of these locations is done using the location quotient analysis, shift share analysis, and typology class.

The results of LQ analysis showed that the agricultural sector is the leading sector in Gorontalo Province with an LQ score $>1$ (Table 2). Almost all regencies in Gorontalo Province have an economic base in the agricultural sector. The regencies with the superior agricultural sector are Boalemo Regency, Gorontalo Regency, Pohuwato Regency, and North Gorontalo Regency. The agricultural sector being superior in Gorontalo Province shows that agricultural products in Gorontalo are not only able to meet local needs but are also able to be sent to other regions or even exported abroad. This shows that the agricultural sector does not only depend on internal strength or local demand, but also on external demand. This supports the implementation of agropolitan due to agropolitan products.

Shift share analysis of the agricultural sector also needs to be carried out to find out the changes of the economic structure in the agricultural sector of each regency or city in Gorontalo Province, so that the economic growth and competitiveness of the agricultural sector in the regency or city can be known. The results of shift share analysis

TABLE 3. Relative position of Gorontalo Province's agricultural sector in 2010-2014 and 2014-2017 based on shift share analysis (Statistics Indonesia 2019).

\begin{tabular}{lllll}
\hline Differential shift (DS) & \multicolumn{2}{c}{ Proportional shift (PS) 2010-2014 } & Proportional shift (PS) 2014-2017 \\
\cline { 2 - 5 } & Positive (+) & Negative (-) & Positive (+) & Negative (-) \\
\hline Positive (+) & Type I (Rapid growth) & $\begin{array}{l}\text { Type I (Rapid growth): Bone } \\
\text { Bolango, North Gorontalo }\end{array}$ & $\begin{array}{l}\text { Type I (Rapid growth): Bone } \\
\text { Bolango, North Gorontalo }\end{array}$ & Type II (Tended to have potential) \\
Negative (-) & Type III (Developing) & $\begin{array}{l}\text { Type III (Developing): } \\
\text { Boalemo, Gorontalo, } \\
\text { Pohuwato, Gorontalo City }\end{array}$ & $\begin{array}{l}\text { Type III (Developing): } \\
\text { Boalemo, Gorontalo, } \\
\text { Pohuwato, Gorontalo City }\end{array}$ \\
\hline
\end{tabular}

TABLE 4. Klassen typology of Gorontalo Province in 2014 and 2017 (Statistics Indonesia 2019).

\begin{tabular}{|c|c|c|c|c|}
\hline \multirow{3}{*}{$\begin{array}{l}\text { Economic } \\
\text { growth rate }(r)\end{array}$} & \multicolumn{2}{|c|}{2014} & \multicolumn{2}{|c|}{2017} \\
\hline & \multicolumn{2}{|c|}{ GDRP (Gross Domestic Regional Product) per capita } & \multicolumn{2}{|c|}{ GDRP (Gross Domestic Regional Product) per capita } \\
\hline & $\mathrm{Yi}>\mathrm{Y}$ & $Y i<Y$ & Yi>Y & $Y i<Y$ \\
\hline ri>r & $\begin{array}{l}\text { Fast-developing and } \\
\text { fast-growing regions: } \\
\text { Pohuwato Regency, } \\
\text { Gorontalo City }\end{array}$ & $\begin{array}{l}\text { Rapidly developing region: } \\
\text { Boalemo Regency, Gorontalo } \\
\text { Regency, Bone Bolango } \\
\text { Regency }\end{array}$ & $\begin{array}{l}\text { Rapidly developed and } \\
\text { fast-growing regions: } \\
\text { Pohuwato Regency, } \\
\text { Gorontalo City }\end{array}$ & $\begin{array}{l}\text { Rapidly developing region: } \\
\text { Gorontalo Regency, Bone } \\
\text { Bolango Regency, North } \\
\text { Gorontalo Regency }\end{array}$ \\
\hline$r i<r$ & $\begin{array}{l}\text { Advanced but oppressed } \\
\text { area: - }\end{array}$ & $\begin{array}{l}\text { Relatively lagging region: } \\
\text { North Gorontalo Regency }\end{array}$ & $\begin{array}{l}\text { Advanced but oppressed } \\
\text { area: - }\end{array}$ & $\begin{array}{l}\text { Relatively lagging region: } \\
\text { Boalemo Regency }\end{array}$ \\
\hline
\end{tabular}


showed that in 2010-2014, Pohuwato Regency had a development in the agricultural sector that tended to have potential because it had positive differential shift and negative proportional shift values (Table 3). Districts and other cities were categorized as under-developed in the agricultural sector because the value of both of the two was negative. In period of 2014-2017, there was a change in the development of the agricultural sector. Bone Bolango Regency and North Gorontalo Regency were the regions that experienced rapid growth, while Boalemo Regency, Gorontalo Regency, Pohuwato Regency, and Gorontalo City were the regions with a developing agricultural sector.

The results of the LQ and SS analysis and Klassen typology together show that Pohuwato Regency has an agricultural base sector and its regional economic development is in the fast-growing category (Table 4). Another regency that has potential is Gorontalo Regency, but its economic growth needs to be improved.

Agropolitan programs must be implemented for superior commodities in the area. The leading commodity in Gorontalo Province is corn. Production as the result of corn harvests in Gorontalo Province has the highest amount compared with other crops. The corn production tends to fluctuate, as shown in Figure 7, but it still has had the largest quantity. This gives it high potential for developing agropolitan using corn commodities.

Corn yields in Gorontalo Province can supply local, inter-island, and external corn needs. Figure 8 shows that in 2015 , the corn commodity had the largest export volume, with $75.88 \%$ of the total volume of exports being corn. This presents a good opportunity for marketing corn as agricultural products. The volume of exports can be increased if corn production increases. With the existence of an agropolitan system, the opportunity to increase the ex-

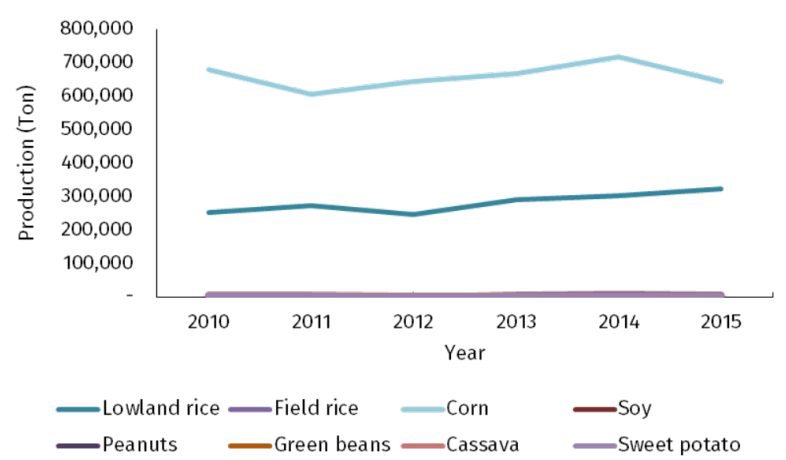

FIGURE 7. Food crop production in Gorontalo Province in 2010-2015. Source: Statistics Indonesia (2019).

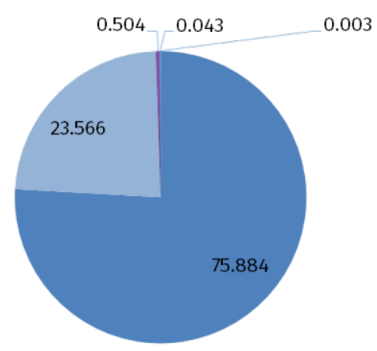

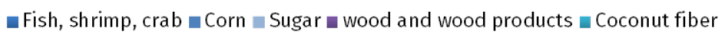

FIGURE 8. Percentage of export volume for each class of goods in Gorontalo Province in 2015. Source: Statistics Indonesia (2019). port volume of corn commodities rises. This will increase the income of the agricultural sector and can improve the welfare of workers who play a role in it.

Agropolitan must be applied in each regency as an autonomous unit that is independent. Each regency has a different role. Regencies that are in the center of government and the economy serve as centers of agribusiness. The center of agribusiness includes agricultural processing industries, trade in agricultural products (including for export), capital facilities, services, and agrotourism. Other districts that have extensive agricultural land are used as an area for the growth of corn farming with various facilities and infrastructures that support the increasing productivity and quality of the corn harvest.

The relationship between the agribusiness center and the corn-producing areas surrounding it is reciprocal. Both of them need each other. Agricultural areas producing agricultural products develop business (on-farm) and processed products on household scale (off-farm), while the business center provides facilities to develop agricultural businesses such as capital, technology, marketing, service, and information of results processing (Davies and Quinlivan 2006). Management of farmer groups is also important, so that agriculture is integrated between the existing fields in order to increase crop productivity.

This agropolitan implementation will be able to absorb a high amount of labor from the process of input of seeds and fertilizers for agriculture, agricultural land management, distribution, marketing, to various other support systems such as technology, energy, services, and logistics. Each process requires a variety of workers with their respective expertise. Good agropolitan management can also increase the productivity of agriculture itself. This can occur because integrated management can increase crop yields with various technologies that support the process of corn growth.

Agropolitan programs that run well can increase people's income. The existence of a well-integrated and wellmanaged program can also improve the work ethos of farmers to continue to always improve land productivity. This will indirectly reduce the level of poverty in terms of the economy. Various cash-intensive programs carried out by the Ministry of Public Works, State-owned Enterprises (Badan Usaha Milik Negara, or BUMN), Health and Transportation can also increase community income by supporting agropolitan programs (Fatkhiati et al. 2015). The program of superior product for rural areas (prukades) that is carried out by the Village Minister, Development of Under-developed Areas, and Migration can also support the agropolitan program. Prukades is focused on corn and coconut commodities with a yield of 500,000 tons in 2017 for corn (Fatkhiati et al. 2015). These results can support efforts to reduce poverty in Gorontalo, especially if integrated with agropolitan programs.

\section{CONCLUSIONS}

Gorontalo Province is among the five provinces with the highest percentage of poor people in Indonesia. In 2017, $17.14 \%$ of the population in Gorontalo was considered to be poor. More than $60 \%$ of the poor population work as farmers. Poverty in Gorontalo Province is structural poverty, because it is caused by the inability of the province's systems and structures to provide employment opportunities for the community. The main cause of poverty in Gorontalo Province is the increase of its population, which is dominated by working people, but is still nonetheless unable 
to match the increasing requirements of job opportunities. This has resulted in a rise in the number of unemployed people, whether it be open unemployment or partial unemployment. The limited existing employment in Gorontalo Province causes the population to work within what is available, so the income they earn is low. Low income causes the population to be unable to fulfill their basic needs.

Many government programs have been carried out to overcome the problem of poverty in Gorontalo Province. However, these programs have not been able to fully deal with the problem of poverty. Agropolitan is one of the solutions to reduce poverty in Gorontalo Province, given that the agricultural sector is an economic base sector in the province. Agropolitan is a city of agriculture that is able to grow and develop due to the running of agribusiness systems and works and is able to serve, encourage, and attract agricultural development activities in the surrounding area. Pohuwato and Gorontalo Regencies both have the potential to be agropolitan areas, because they have an agricultural sector that is more developed and has higher potential than the the other regencies or cities in Gorontalo Province. The agricultural commodity that must be developed in Gorontalo Province is corn, because in terms of quantity and quality, corn from Gorontalo Province is one of the best in Indonesia and has greater opportunities international trade.

\section{ACKNOWLEDGMENTS}

Throughout the writing of this research we have received a great deal of support and assistance. We would first like to thank the Faculty of Geography, Universitas Gadjah Mada, as well as Statistics Indonesia, who have provided the various data we use.

\section{REFERENCES}

Aneta A. 2010. Implementasi kebijakan Program Penanggulangan Kemiskinan Perkotaan (P2KP) di Kota Gorontalo [Implementation of the Urban Poverty Reduction Program (P2KP) policy in Gorontalo City]. Jurnal Ilmu Administrasi Publik. 1(1):54-65. doi:10.26858/jiap.v1i1.132.

Davies A, Quinlivan G. 2006. A panel data analysis of the impact of trade on human development. J Soc Econ. 35(5):868-876. doi:10.1016/j.socec.2005.11.048.

Department of Agriculture of the Republic of Indonesia. 2002. Pedoman umum pengembangan kawasan agropolitan dan pedoman program rintisan pengembangan kawasan agropolitan [Common development guidelines for the agropolitan region and guidelines for human resources development programme]. Jakarta: Badan Pengembangan Sumberdaya Manusia Departemen Pertanian.

Dwiputra DS, Rahmanu YA, Tofani AS, Naufal M, Arsy An Nisa KS, Bariq JM, Putri RF. 2019. Nett present value (NPV) analysis for projection of feasibility of coastal sand dune tourism in Parangtritis Village. E3S Web Conf. 76:05002. doi:10.1051/e3sconf/20197605002.

Fatkhiati S, Tjiptoherijanto P, Rustiadi E, Thayib MH. 2015. Sustainable agropolitan management model in the highland of tropical rainforest ecosystem: the case of Selupu Rejang agropolitan area, Indonesia. Procedia Environ Sci. 28:613-622. doi:10.1016/j.proenv.2015.07.0 72.

Helmi, Azhari R, Henmaidi, Silfia, Riyadhie I. 2019. Identi- fying key factors affecting integrated and sustainable development of red onion horticulture cluster area. Int J Adv Sci Eng Inf Technol. 9(2):448. doi:10.18517/ijaseit 9.2.6875.

Hendayana R. 2003. Aplikasi metode Location Quotient (LQ) dalam penentuan komoditas unggulan nasional [The Location Quotient Method application for defining a top national commodity]. Jurnal Informatika Pertanian. 12:1-21.

Hudaya D. 2009. Faktor faktor yang mempengaruhi tingkat kemiskinan di Indonesia [Factors that affect the poverty level in Indonesia]. Undergraduate thesis. [Bogor]: Institut Perrtanian Bogor.

Muta'ali L. 2015. Teknik analisis regional untuk perencanaan wilayah tata ruang dan lingkungan [Regional analysis techniques for planning area and enviroment]. Yogyakarta: Badan Penerbit Fakultas Geografi Universitas Gadjah Mada.

Nugroho RA. 2012. Analisis pertumbuhan ekonomi dan pengembangan sektor potensial di Kabupaten Jepara (pendekatan model basis ekonomi) [Economic growth analysis and potential sector development in Jepara District (economic based model approach)]. Undergaduate thesis. [Surakarta]: Universitas Muhammadiyah Surakarta.

Perloff HS, Lampard E, Keith R. 1960. Regions, resources, and economic growth. Baltimore: The Johns Hopkins Press.

Putri RF, Wibirama S, Giyarsih SR, Pradana A, Kusmiati Y. 2019. Landuse change monitoring and population density analysis of Penjaringan, Cengkareng, and Cakung urban area in Jakarta Province. E3S Web Conf. 76:03004. doi:10.1051/e3sconf/20197603004.

Putri RF, Wibirama S, Sukamdi, Giyarsih SR. 2018. Population condition analysis of Jakarta land deformation area IOP Conf Ser: Earth Environ Sci. doi:10.1088/1755-131 5/148/1/012007.

Robinson T. 2005. Ekonomi regional teori dan aplikasi [Economic regional theory and aplplication]. Jakarta: Bumi Aksara.

Statistics Indonesia. 2019. Provinsi Gorontalo dalam angka 2018 [Gorontalo Province in figures 2018]. Gorontalo: Statistics Indonesia.

Suroyo TB, Handayani W. 2014. Pengembangan kawasan agropolitan di Kabupaten Kulonprogo, Daerah Istimewa Yogyakarta [Agropolitan area development in Kulon Progo District, Spesial Region of Yogyakarta]. Jurnal Perencanaan Wilayah dan Kota. 25(3):243-261. doi: 10.5614/jpwk.2015.25.3.5.

Sutikno, Maryunani. 2007. Analisis potensi dan daya saing kecamatan sebagai pusat pertumbuhan satuan wilayah pengembangan (SWP) Kabupaten Malang [Analysis of subdistricts' potential and competitiveness as growth centers in Malang District]. J Indones Appl Econ. 1(1):117.

Tazkiya. 2015. Faktor-faktor penyebab kemiskinan [Poverty causing factors]. Jurnal Keislaman, Kemasyarakatan dan Kebudayaan. 16(1):1-30.

Yulianto A, Kusumaningrum PB, Daniati A, Nurvitasari S, Putri RF. 2019. Temporal-spatial analysis in accordance with gender development index on the improvement of the quality of women in central kalimantan province. E3S Web Conf. 76:05003. doi:10.1051/e3sconf/201976 05003. 